\begin{tabular}{|c|l|}
\hline Title & $\begin{array}{l}\text { Synthesis of } \beta \text { - Boryl-a , } \beta \text { - - unsaturated Carbonyl Compounds via Palladium-Catalyzed Cross Coupling Reaction of } \\
\text { Bis(pinacolato)diboron with V inyl Triflates }\end{array}$ \\
\hline Author(s) & Miyaura, Norio; Ishiyama, Tatsuo; Takagi, Jun; Kamon, A kihiro \\
\hline Citation & $\begin{array}{l}\text { Synlett, 2002(11), 1880-1882 } \\
\text { https://doi.org/10.1055/s 2002-34869 }\end{array}$ \\
\hline Issue Date & 2002-11 \\
\hline Doc URL & http://hdl.handle.net/2115/56227 \\
\hline Type & article (author version) \\
\hline File Information & (34) B-B + X-Enone (Com).pdf \\
\hline
\end{tabular}

Instructions for use 


\title{
Synthesis of $\beta$-Boryl- $\alpha, \beta$-unsaturated Carbonyl Compounds via Palladium-Catalyzed Cross-Coupling Reaction of Bis(pinacolato)diboron with Vinyl Triflates
}

\author{
Jun Takagi, Akihiro Kamon, Tatsuo Ishiyama, ${ }^{*}$ Norio Miyaura* \\ Division of Molecular Chemistry, Graduate School of Engineering, \\ Hokkaido University, Sapporo 060-8628, Japan \\ Fax +81-11-706-6562, +81-11-706-6561; E-mail: \\ ishiyama@org-mc.eng.hokudai.ac.jp, \\ miyaura@org-mc.eng.hokudai.ac.jp \\ Received $X X X X$
}

\begin{abstract}
Cross-coupling reaction of bis(pinacolato)diboron with $\beta$-(trifluoromethanesulfonyloxy)- $\alpha, \beta$-unsaturated carbonyl compounds was carried out in the presence of $\mathrm{PdCl}_{2}\left(\mathrm{PPh}_{3}\right)_{2}-2 \mathrm{PPh}_{3}(3 \mathrm{~mol} \%)$ and $\mathrm{KOPh}$ in toluene or $\mathrm{K}_{2} \mathrm{CO}_{3}$ in dioxane for the synthesis of cyclic and acyclic $\beta$-boryl- $\alpha, \beta$-unsaturated esters, amides, and ketones in high yields.
\end{abstract}

Key words: diboron, vinyl triflate, palladium, cross-coupling, catalysis

$\beta$-Boryl- $\alpha, \beta$-unsaturated carbonyl compounds are attractive synthetic intermediates which allow inter- or intramolecular Diels-Alder reaction, ${ }^{1}$ asymmetric dipolar cycloaddition or 1,4 -addition, ${ }^{2}$ cyclopropanation, ${ }^{3}$ and radical addition. ${ }^{4}$ Although $\beta$-borylacrylates are available via hydroboration of propiolic acid esters, ${ }^{1,5}$ preparation of the corresponding ketone and aldehyde derivatives requires a multi-step procedure ${ }^{1,6}$ and there are few reports for cyclic or polysubstituted derivatives. ${ }^{7}$ In connection with our interest in the synthesis of organoboron compounds via the cross-coupling reaction of diborons with organic electrophiles ${ }^{8}$ including aryl, ${ }^{8,9}$ vinyl, ${ }^{8,10}$ allyl, $^{8,11}$ and benzyl ${ }^{8,12}$ halides or triflates, we wish to disclose here a palladium-catalyzed cross-coupling reaction of bis(pinacolato)diboron ${ }^{13}$ ( $\operatorname{pin}_{2} \mathrm{~B}_{2}$, pin $\left.=\mathrm{Me}_{4} \mathrm{C}_{2} \mathrm{O}_{2}\right)$ (1) with vinyl triflates $^{14}$ (2) to yield the corresponding $\beta$-boryl- $\alpha, \beta$-unsaturated carbonyl compounds (3) (Eq. 1).

$$
<<\text { Eq. } 1>>
$$

The effects of bases and solvents on the reaction are shown in Table 1. The conditions previously reported for the coupling of $\operatorname{pin}_{2} \mathrm{~B}_{2} 1$ with vinyl halides or triflates $\left(\mathrm{PdCl}_{2}\left(\mathrm{PPh}_{3}\right)_{2}-2 \mathrm{PPh}_{3} / \mathrm{KOPh} / \text { toluene } / 50{ }^{\circ} \mathrm{C}\right)^{10}$ gave borylated products 3 in high yields for most of the vinyl triflates 2 , but the reaction often resulted in very low yields due to a competitive base-induced side-reaction. For example, the reaction of 1 (1.1 mmol) with ethyl 2-(trifluoromethanesulfonyloxy)-1-cyclopentenecarboxylate (1.0 $\mathrm{mmol})$ in the presence of $\mathrm{PdCl}_{2}\left(\mathrm{PPh}_{3}\right)_{2}-2 \mathrm{PPh}_{3}(0.03 \mathrm{mmol})$ and $\mathrm{KOPh}$ 
$(1.5 \mathrm{mmol})$ in toluene $(6 \mathrm{ml})$ at $50{ }^{\circ} \mathrm{C}$ resulted in $9 \%$ yield (Entry 1$)$. Analysis of the reaction mixture revealed the formation of phenyl triflate $(90 \%)$ resulted by ester-exchange between the triflate and KOPh. ${ }^{15}$ A sterically more hindered $2-\mathrm{MeC}_{6} \mathrm{H}_{4} \mathrm{OK}$ base, which is expected to inhibit the ester-exchange, also produced the corresponding triflate in 69\% yield (Entry 2). Alternatively, use of a $\mathrm{K}_{2} \mathrm{CO}_{3}$ base in dioxane was found to be effective for such substrates sensitive to the phenoxy anion to promote the desired coupling in $67 \%$ yield (Entry 3). Although $\mathrm{K}_{2} \mathrm{CO}_{3}$ was prone to induce further coupling of 3 with 2 giving a dimer of 2 (ca. 30\%), stronger bases such as $\mathrm{K}_{3} \mathrm{PO}_{4}$ further enhanced the dimerization (Entry 4) and weaker bases such as KOAc did not promote the coupling (Entry 5). Use of less-polar solvents such as toluene resulted in low conversion (Entry 6). Although the reactions using $\mathrm{K}_{2} \mathrm{CO}_{3}$ took longer times at $50{ }^{\circ} \mathrm{C}$, the same reactions were completed at $80^{\circ} \mathrm{C}$ within $5 \mathrm{~h}$ in dioxane and $24 \mathrm{~h}$ in toluene, respectively (Entries 7 and 8).

$$
<<\text { Table } 1>>
$$

The palladium-catalyzed cross-coupling of $\operatorname{pin}_{2} \mathrm{~B}_{2} \mathbf{1}$ with the representative vinyl triflates 2 in the presence of $\mathrm{KOPh}$ in toluene at $50{ }^{\circ} \mathrm{C}$ (Method A) or $\mathrm{K}_{2} \mathrm{CO}_{3}$ in dioxane at $80{ }^{\circ} \mathrm{C}$ (Method $\left.\mathrm{B}\right)$ is summarized in Table 2. ${ }^{16}$ All 2 including cyclic or acyclic ester, amide, and ketone derivatives were converted into the corresponding $\beta$-boryl- $\alpha, \beta$-unsaturated carbonyl compounds $\mathbf{3}$ in high yields by either Method A or B. The reactions were faster under the conditions of Method A than those of Method B; however, the yields highly depended upon the substrates. Method A resulted in low yields due to the formation of phenyl triflate (30-90\%) for substrates sensitive to the phenoxy anion, including five-membered ester (Entry 1), six-membered amide (Entry 5), five-membered ketone (Entry 6), and less-hindered six-membered ketone having no substituent at the $\alpha$ carbon (Entry 8). On the other hand, Method A was a better choice for seven- and eight-membered esters (Entries 3 and 4), and acyclic ester (Entry 10), because Method B resulted in the formation of symmetrical 1,3-dienes (15-30\%) arising from dimerization of 2 . The borylation of acyclic ester and amide derivatives of $\mathbf{2}$ having $E$ stereochemistry retained completely the configuration of the double bond to give isomerically pure (Z)-3 in high yields (Entries 10 and 11).

$$
<<\text { Table } 2>>
$$

In general, $E$ or $Z$ configuration of 1-alkenyl halides or triflates can be retained completely in the cross-coupling of organoboron compounds; ${ }^{17}$ however, the amide derivative of triflate (Z)-4 unexpectedly provided the borylated product $(Z)-5$ by Method A and a mixture of $(Z)-5$ and $(E)-5$ (64:36) by Method B (Eq. 2). Monitoring of a benzene- $d_{6}$ solution of the (Z)-4 or $(E)-5$ in the presence of $\mathrm{Pd}\left(\mathrm{PPh}_{3}\right)_{4}$ and $\mathrm{KOPh}$ by ${ }^{1} \mathrm{H}$ NMR and GC at $50{ }^{\circ} \mathrm{C}$ resulted in no conversion into $(E)-4$ or (Z)-5, suggesting the isomerization during the catalytic process. It remains unclear which step is responsible for such isomerization; however, a vinylpalladium(II) species generated by 
oxidative addition of a vinyl halide or triflate to a palladium( $(0)$ complex often undergoes $E-Z$ isomerization. ${ }^{18}$

$$
<<\text { Eq. } 2>>
$$

The direct preparation of $\beta$-boryl- $\alpha, \beta$-unsaturated carbonyl compounds 3 from $\operatorname{pin}_{2} B_{2} 1$ and the corresponding vinyl triflates 2 now allows a one-pot, two-step procedure for the synthesis of ketone or ester derivatives of unsymmetrical 1,3-dienes 7 (Table 3). The stereoselective syntheses of three dienes 7 were easily achieved in $76 \%, 76 \%$, and $77 \%$ yields when the borylation of $2(1.1 \mathrm{mmol})$ with 1 (1.1 mmol) was directly followed by the coupling with another vinyl triflate $6(1.0 \mathrm{mmol}) .{ }^{19}$ A combination of $\mathrm{PdCl}_{2}(\mathrm{dppf})(0.03 \mathrm{mmol})$ and $\mathrm{K}_{3} \mathrm{PO}_{4}(3.0 \mathrm{mmol})$ in dioxane at $80{ }^{\circ} \mathrm{C}$ was recognized to be the best conditions for the second coupling. ${ }^{17}$

$$
<<\text { Table } 3>>
$$

\section{References and Notes}

(1) A recent review: Vaultier, M.; Lorvelec, G.; Plunian, B.; Paulus, O.; Bouju, P.; Mortier, J. In Contemporary Boron Chemistry; Davidson, A. K., Hughes, A. K., Marder, T. B., Wade, K., Eds.; The Royal Society of Chemistry: Cambridge, 2000, 464.

(2) (a) Davies, C. D.; Marsden, S. P.; Stokes, E. S. E. Tetrahedron Lett. 1998, 39, 8513. (b) Davies, C. D.; Marsden, S. P.; Stokes, E. S. E. Tetrahedron Lett. 2000, 41, 4229. (c) Farthing, C. N.; Marsden, S. P. Tetrahedron Lett. 2000, 41, 4235.

(3) Fontani, P.; Carboni, B.; Vaultier, M.; Maas, G. Synthesis 1991, 605.

(4) Guennouni, N.; Lhermitte, F.; Cochard, S.; Carboni, B. Tetrahedron 1995, 51, 6999.

(5) Negishi, E.-i.; Yoshida, T. J. Am. Chem. Soc. 1973, 95, 6837.

(6) Jehanno, E.; Vaultier, M. Tetrahedron Lett. 1995, 36, 4439.

(7) (a) Marcuccio, S. M.; Rodopoulos, M.; Weigold, H. WO 9858935 A1, 1998. (b) Marcuccio, S. M.; Rodopoulos, M.; Weigold, H. 10th International Conference on Boron Chemistry, Durham, England, July 1999, PB-35.

(8) A recent review: Ishiyama, T.; Miyaura, N. J. Organomet. Chem. 2000, 611, 392.

(9) (a) Ishiyama, T.; Murata, M.; Miyaura, N. J. Org. Chem. 1995, 60, 7508. (b) Ishiyama, T.; Itoh, Y.; Kitano, T.; Miyaura, N. Tetrahedron Lett. 1997, 38, 3447. (c) Ishiyama, T.; Ishida, K.; Miyaura, N. Tetrahedron 2001, 57, 9813.

(10) (a) Takahashi, K.; Takagi, J.; Ishiyama, T.; Miyaura, N. Chem. Lett. 2000, 126. (b) Takagi, J.; Takahashi, K.; Ishiyama, T.; Miyaura, N. J. Am. Chem. Soc. 2002, 124, 8001 and difficulties to apply the reaction conditions used for the borylation of aryl electrophiles to that of vinyl electrophiles have been described therein.

(11) (a) Ishiyama, T.; Ahiko, T.-a.; Miyaura, N. Tetrahedron Lett. 1996, 37, 6889. (b) Ahiko, T.-a.; Ishiyama, T.; Miyaura, N. Chem. Lett. 1997, 811.

(12) Ishiyama, T.; Oohashi, Z.; Ahiko, T.-a.; Miyaura, N. Chem. Lett. 
2002, 780 .

(13) (a) Nöth, H. Z. Naturforsch. 1984, 39b, 1463. (b) Ishiyama, T.; Murata, M.; Ahiko, T.-a.; Miyaura, N. Org. Synth. 2000, 77, 176.

(14) Reviews: (a) Stang, P. J.; Hanack, M.; Subramanian, L. R. Synthesis 1982, 85. (b) Ritter, K. Synthesis 1993, 735.

(15) Subramanian, L. R.; Hanack, M.; Chang, L. W. K.; Imhoff, M. A.; Schleyer, P. v. R.; Effenberger, F.; Kurtz, W.; Stang, P. J.; Dueber, T. E. J. Org. Chem. 1976, 41, 4099.

(16) A representative procedure for 3: A flask placed with $\mathrm{PdCl}_{2}\left(\mathrm{PPh}_{3}\right)_{2}(0.03 \mathrm{mmol}), \mathrm{PPh}_{3}(0.06 \mathrm{mmol}), \mathrm{pin}_{2} \mathrm{~B}_{2} 1$ (1.1 mmol), and $\mathrm{KOPh}$ or $\mathrm{K}_{2} \mathrm{CO}_{3}(1.5 \mathrm{mmol})$ was flushed with nitrogen. Toluene or dioxane $(6 \quad \mathrm{ml})$ and ethyl

2-(trifluoromethanesulfonyloxy)-1-cyclohexenecarboxylate $\quad(1.0$ mmol) were then added. The resulting mixture was stirred at $50{ }^{\circ} \mathrm{C}$ or $80{ }^{\circ} \mathrm{C}$ for the period shown in Table 2 . The product was isolated by chromatography over silica gel followed by Kugelrohr distillation to give an analytically pure sample: ${ }^{1} \mathrm{H} \mathrm{NMR}\left(400 \mathrm{MHz}, \mathrm{CDCl}_{3}, \mathrm{TMS}\right) \delta$ $1.27(\mathrm{t}, 3 \mathrm{H}, J=7.2 \mathrm{~Hz}), 1.33(\mathrm{~s}, 12 \mathrm{H}), 1.55-1.65$ (m, $4 \mathrm{H}), 2.20-2.25$ $(\mathrm{m}, 4 \mathrm{H}), 4.21(\mathrm{q}, 2 \mathrm{H}, J=7.2 \mathrm{~Hz}) ;{ }^{13} \mathrm{C} \mathrm{NMR}\left(100 \mathrm{MHz}, \mathrm{CDCl}_{3}\right.$, TMS) $\delta 14.25,21.42,21.85,24.12,24.77,27.93,60.70,83.34,134.24$, 169.19; HRMS, Found: $m / z, 280.1846$. Calcd for $\mathrm{C}_{15} \mathrm{H}_{25} \mathrm{BO}_{4}: \mathrm{M}^{+}$, 280.1846 .

(17) Recent reviews: (a) Miyaura, N.; Suzuki, A. Chem. Rev. 1995, 95, 2457. (b) Suzuki, A. In Metal-Catalyzed Cross-Coupling Reactions; Diederich, F., Stang, P. J., Eds.; Wiley-VCH: Weinheim, 1998, 49. (c) Miyaura, N. Top. Curr. Chem. 2002, 219, 11.

(18) (a) Zargarian, D.; Alper, H. Organometallics 1991, 10, 2914. (b) Arcadi, A.; Cacchi, S.; Fabrizi, G.; Moro, L. Eur. J. Org. Chem. 1999, 1137.

(19) The 1,3-dienes 7 shown in Table 3 could be purified by column chromatography over silica gel to give analytically pure samples. 

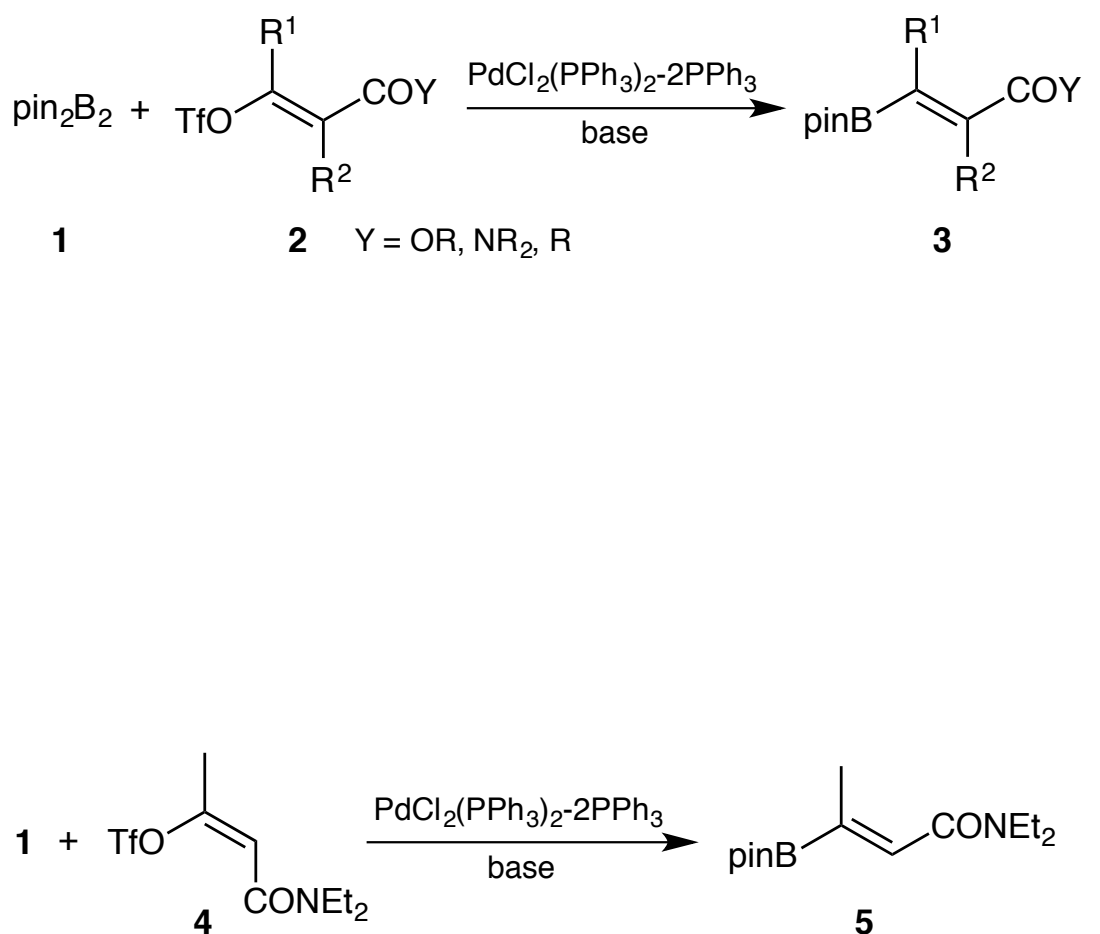
$Z>99 \%$

$\mathrm{KOPh} /$ toluene $/ 50^{\circ} \mathrm{C} / 1 \mathrm{~h}: \quad 88 \%(Z>99 \%)$ $\mathrm{K}_{2} \mathrm{CO}_{3} /$ dioxane $/ 80{ }^{\circ} \mathrm{C} / 5 \mathrm{~h}: \quad 91 \%(Z=64 \%)$ 
Table 1 Effects of Bases and Solvents ${ }^{a}$

\begin{tabular}{clccc}
\hline Entry & Base/Solvent & Temp $/{ }^{\circ} \mathrm{C}$ & Time/h & Yield $/ \%^{b}$ \\
\hline 1 & $\mathrm{KOPh} /$ toluene & 50 & 2 & $9^{c}$ \\
2 & $2-\mathrm{MeC}_{6} \mathrm{H}_{4} \mathrm{OK} /$ toluene & 50 & 2 & $4^{d}$ \\
3 & $\mathrm{~K}_{2} \mathrm{CO}_{3} /$ dioxane & 50 & 16 & $67^{e}$ \\
4 & $\mathrm{~K}_{3} \mathrm{PO}_{4} /$ dioxane & 50 & 16 & $58^{e}$ \\
5 & $\mathrm{KOAc}_{\text {dioxane }}$ & 50 & 16 & 4 \\
6 & $\mathrm{~K}_{2} \mathrm{CO}_{3} /$ toluene & 50 & 16 & 1 \\
7 & $\mathrm{~K}_{2} \mathrm{CO}_{3} /$ dioxane & 80 & 5 & $67^{e}$ \\
8 & $\mathrm{~K}_{2} \mathrm{CO}_{3} /$ toluene & 80 & 24 & $65^{e}$ \\
\hline
\end{tabular}

${ }^{a}$ The coupling reaction of diboron $1(1.1 \mathrm{mmol})$ with ethyl 2-(trifluoromethanesulfonyloxy)-1-cyclopentenecarboxylate (1.0 mmol) was carried out in the presence of $\mathrm{PdCl}_{2}\left(\mathrm{PPh}_{3}\right)_{2}(0.03$ $\mathrm{mmol}), \mathrm{PPh}_{3}(0.06 \mathrm{mmol})$, and base $(1.5 \mathrm{mmol})$ in $6 \mathrm{ml}$ of solvent. ${ }^{b} \mathrm{GC}$ yields based on the triflate.

${ }^{c}$ The reaction accompanied PhOTf (90\%).

${ }^{d}$ The reaction produced $2-\mathrm{MeC}_{6} \mathrm{H}_{4} \mathrm{OTf}(69 \%)$

${ }^{e}$ The reactions gave a dimer of the triflate (30-40\%). 
Table 2 Synthesis of 1-Alkenylboronates 3 (Eq. 1) ${ }^{a}$

\begin{tabular}{|c|c|c|c|}
\hline \multirow{2}{*}{ Entry } & \multirow{2}{*}{ Triflate 2} & \multicolumn{2}{|c|}{ Yield $/ \%{ }^{b}$} \\
\hline & & Method $\mathrm{A}^{c}$ & Method $\mathrm{B}^{d}$ \\
\hline & & & \\
\hline 1 & & $9(2 \mathrm{~h})$ & $67(5 \mathrm{~h})$ \\
\hline 2 & & $78(1 \mathrm{~h})$ & $91(6 \mathrm{~h})$ \\
\hline 3 & & $76(1 \mathrm{~h})$ & $74(3 \mathrm{~h})$ \\
\hline 4 & & $72(1 \mathrm{~h})$ & $60(5 \mathrm{~h})$ \\
\hline 5 & & $60(6 \mathrm{~h})$ & 98 (3 h) \\
\hline 6 & & $21(1 \mathrm{~h})$ & 78 (2 h) \\
\hline 7 & & $81(2 \mathrm{~h})$ & $91(5 \mathrm{~h})$ \\
\hline 8 & & $25(2 \mathrm{~h})$ & 78 (2 h) \\
\hline 9 & & $72(1 \mathrm{~h})$ & 77 (3 h) \\
\hline 10 & & $93(1 \mathrm{~h})$ & $72(3 \mathrm{~h})$ \\
\hline 11 & & $75(1 \mathrm{~h})$ & $76(2 \mathrm{~h})$ \\
\hline
\end{tabular}

${ }^{a}$ All reactions were conducted by using diboron 1 (1.1 mmol), triflate 2 (1.0 mmol), $\mathrm{PdCl}_{2}\left(\mathrm{PPh}_{3}\right)_{2}(0.03 \mathrm{mmol}), \mathrm{PPh}_{3}(0.06 \mathrm{mmol})$, base (1.5 $\mathrm{mmol})$, and solvent $(6 \mathrm{ml})$.

${ }^{b} \mathrm{GC}$ yields based on triflates 2 .

${ }^{c}$ Method A: $\mathrm{KOPh} /$ toluene $/ 50{ }^{\circ} \mathrm{C}$.

${ }^{d}$ Method B: $\mathrm{K}_{2} \mathrm{CO}_{3} /$ dioxane $/ 80{ }^{\circ} \mathrm{C}$. 
Table 3 One-Pot Synthesis of 1,3-Dienes $7^{a}$

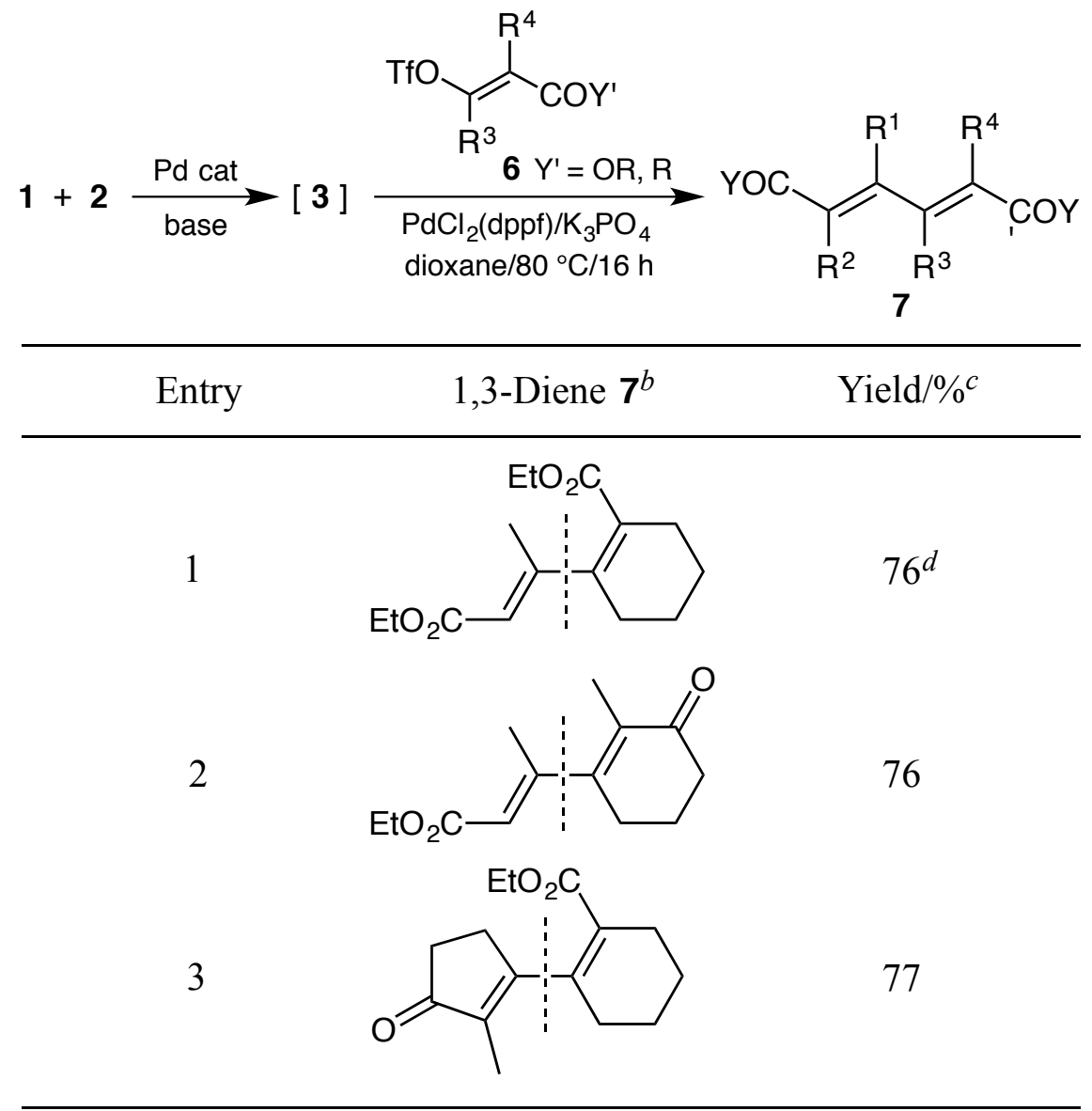

${ }^{a}$ To a solution of 1-alkenylboronate 3 resulted by the reaction of diboron $1(1.1 \mathrm{mmol})$ with triflate $2(1.1 \mathrm{mmol})$ in toluene or dioxane $(4 \mathrm{ml})$ were added second triflate 6 (1.0 mmol), $\mathrm{PdCl}_{2}$ (dppf) (0.03 mmol), $\mathrm{K}_{3} \mathrm{PO}_{4}$ $(3.0 \mathrm{mmol})$, and dioxane $(4 \mathrm{ml})$, and the mixture was stirred at $80^{\circ} \mathrm{C}$ for $16 \mathrm{~h}$.

${ }^{b}$ Left part of dotted line comes from $\mathbf{2}$ and right part from $\mathbf{6}$.

${ }^{c}$ Isolated yields based on triflates $\mathbf{6}$.

${ }^{d} \mathrm{GC}$ yield after $5 \mathrm{~h}$. 
Use for Graphical Abstract Only

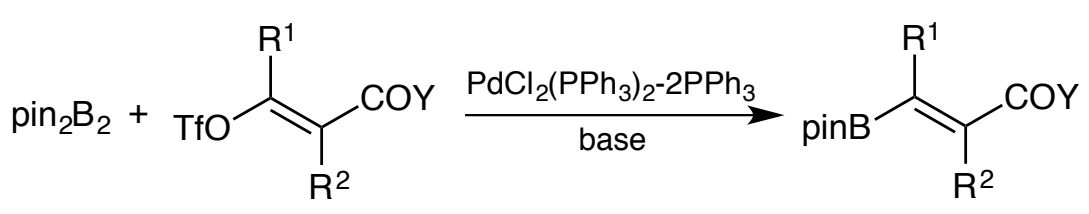

pin $=\mathrm{Me}_{4} \mathrm{C}_{2} \mathrm{O}_{2} \quad \mathrm{Y}=\mathrm{OR}, \mathrm{NR}_{2}, \mathrm{R}$ 